\title{
EFFECTS OF EXPERIMENTAL APPROACH OF TEACHING CHEMISTRY ON SCIENTIFIC PROCESS SKILLS ACQUISITION IN SECONDARY SCHOOLS IN TESO SOUTH SUB-COUNTY
}

\author{
Raymond L. Eluket, Peter Waswa and Samuel Lutta \\ University of Eldoret, P.O BOX 1125-30100 Eldoret Kenya \\ http://doi.org/10.35410/IJAEB.2019.4456
}

\begin{abstract}
a science, the subject is experimental in nature where learning should start with hands on experiences and not abstract definitions. In this approach of teaching, the learners interact with apparatus, make observations and come up with conclusions. The study was intended to explore the effects of experimental work on knowledge mastery in Chemistry at secondary school level in Teso South Sub-County. The choice of the study was motivated by poor experimental skills of learners in chemistry. The study was also ignited by the KNEC reports of 2016 and 2017 which pointed out the need for practical work among secondary school learners. The study was useful to chemistry and other science subjects, teacher training institutions, Kenya National Examination Council and finally Ministry of Education. The units of analysis in the study were form three students. The study employed the constructivism theory. The study targeted 1216 form 3 students in 18 public secondary schools of Teso South Sub-County. Out of this number 333 were stratified sampled to participate in the study. The study employed the quantitative research methodology and quasi-experimental design. Seven science process skills(observing, measuring, recording, classifying, setting-up apparatus, reading scales, manipulating data) were examined whether students acquired them perfectly or to small extent or unable. The t-test of these three dimensions gave $\mathrm{p}=0.0026, \mathrm{p}=0.0016$ and $\mathrm{p}=0.0238$ respectively, to mean that there was a significant difference in the acquisition of the science process skills for the experimental and control groups.
\end{abstract}

Keywords: Experimental approach, scientific process skills, acquisition.

\section{INTRODUCTION}

Chemistry is one of the very important sciences in Kenyan secondary schools. Being a science, the subject is experimental in nature where learning should start with hands on experiences and not abstract definitions. Development of practical skills has been measured in research less frequently than mastery of knowledge or subject matter or scientific reasoning. Practical outcomes deserve more attention especially for laboratory experiments that are critical part of vocational or technical training in some secondary school programs. The major goal of this is to train students for jobs in laboratory settings, use and read sophisticated instruments and carry out standardized experimental procedures. Therefore, the critical question about acquiring these skills through laboratory experiences may not be whether laboratory experiments help students 
learn them, but how their experiences can be constructed so as to be most effective in teaching process skills. According to author(1), practical work is any science teaching activity which involves students working individually or in small groups, manipulating and or observing real objects and materials as opposed to the virtual world. Author (2), defined practical work as a learning experience in which students interact with materials or with secondary sources of data to observe and understand the natural world. Therefore, practical technique of teaching is a modern technique that involves first-hand experience through observation, manipulation of apparatus and analysis of results obtained. To improve technological aspect, some countries in the world that are struggling to achieve a developed nation status have undertaken the challenge of placing greater emphasis on science $(3)$.

According to (4), poor quality science education is common in many developing countries: Moreover, in these countries, the number of students studying science at secondary school level is very small, with even fewer are pursuing sciences in tertiary level.A study by (5), on the national science education standards in the United States and other contemporary science education suggested that science laboratories have the potential to be an important medium for introducing students to central conceptual and procedural knowledge and skills in science. This finding was supported by another research study by (6), on the teaching and learning for the $21^{\text {st }}$ century which established that, models of education designed to meet the needs of the industrial past are inadequate for the many challenges and opportunities facing $21^{\text {st }}$ century students.

The KNEC reports of 2016 and 2017 recommended that science teachers in secondary schools should adopt the practical approach of teaching. This was after the realization of poor experimental skills in chemistry paper 3 by the candidates. In addition, the report also emphasized on the equipping of the schools with the necessary apparatus and chemicals, training of the students on how to take precautions in order to make accurate observations.

\section{METHODOLOGY}

The study adapted a quasi-experimental research design. The methods in this study were used to examine the effects of experimental approach on science process skills acquisition.

\section{Population and sample of the study}

The population of the study consisted of all the form three students in Teso South Sub-county of Busia County. The sub-county has a total of 18 public secondary schools. Target population was chosen because chemistry is one of the compulsory science subjects in most schools in the subcounty. The sample size is form three students from six mixed secondary schools (30\% of the total population) whose number was 333. The sampling techniques employed werestratified sampling.

\section{Instruments}

The researcher used one (1) instrument. The instrument was observation checklist for the skills acquisition (OCFSA) developed by the researcher and used during practical's in the laboratory. 


\section{Validation of the instrument}

The three instruments were piloted in one of the schools in the neighboring Nambale sub-county. The school was a mixed secondary school similar and in same category with the target schools in Teso South sub-county. The piloting was to ensure the comprehensibility, validity and reliability of the instruments. The students selected were not included in the main study.

\section{Data collection and analysis}

The respondents proficiency in experimental skills were garnered from each of the sub-topics learnt in class were determined using the Observation Checklists for Skills Acquisition (OCFSA) administered to each study group. The OCFSA determined proficiency and competency in aspects of science process skills. This was done the last week of the study. Data obtained was analysed using both inferential and descriptive methods.

\section{RESULTS}

Science process skills investigated a range of skills starting with observing, measuring, recording, reading scales, setting up apparatus and manipulation of experimental data. The proficiency in these six skills was determined using an observation check list for these skills (Appendix III). Then t-tests for both experimental and control groups were carried out and recorded as in Table 4.2 below.

Table 4.2: t-test analysis for process skills acquisition for experimental and control group.

\begin{tabular}{|lllllll|}
\hline Competence & Test & Average & Standard deviation & T-test & Df & P-value \\
\hline Not able & Experimental & 4.7857 & 3.2148 & -2.4000 & 27 & 0.0238 \\
& Control & 7.8571 & 3.5487 & & & \\
To small extent & Experimental & 3.2857 & 1.3828 & -2.5764 & 27 & 0.0160 \\
& Control & 5.7143 & 3.2446 & & \\
Perfect & Experimental & 28.9286 & 8.2692 & 3.3294 & 27 & 0.0026 \\
& Control & 18.0000 & 9.0808 & & & \\
\hline
\end{tabular}

The data in table 4.2 shows the outcome of scientific process skills acquisition of the six skills for both experimental and control groups.

The results were also presented as shown in the following figures 


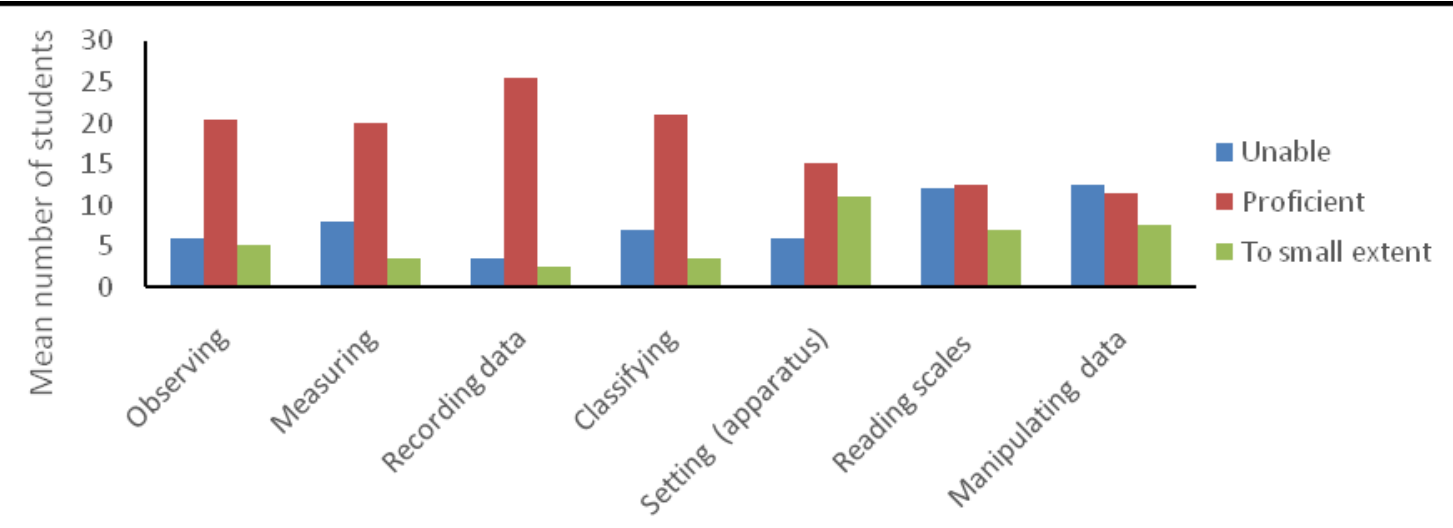

Science process skills

Fig 1: science process skills for control group.

Most students were proficient in all the skills except in reading and manipulating data where the number of those unable surpassed the proficient.

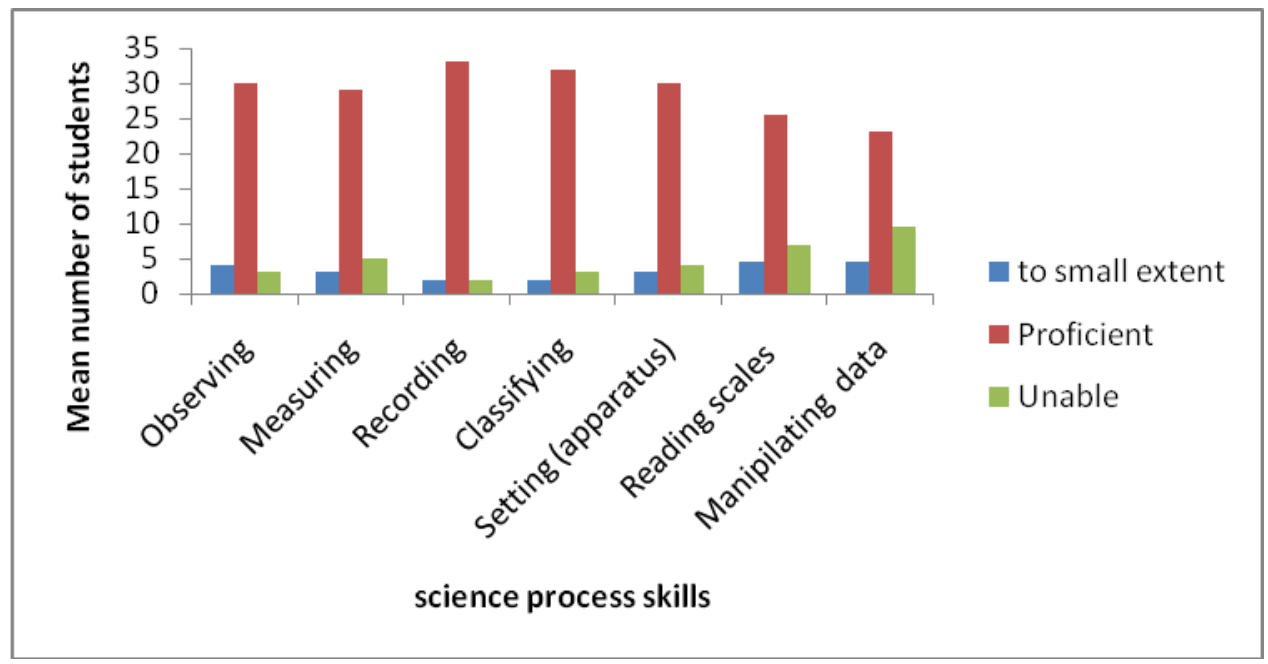

Figure 2: Scientific process for the experimental group

In experimental group, averagely $30 \%$ of students were proficient in all the skills. This was followed by the number of those who were unable then those who were able to small extent. 


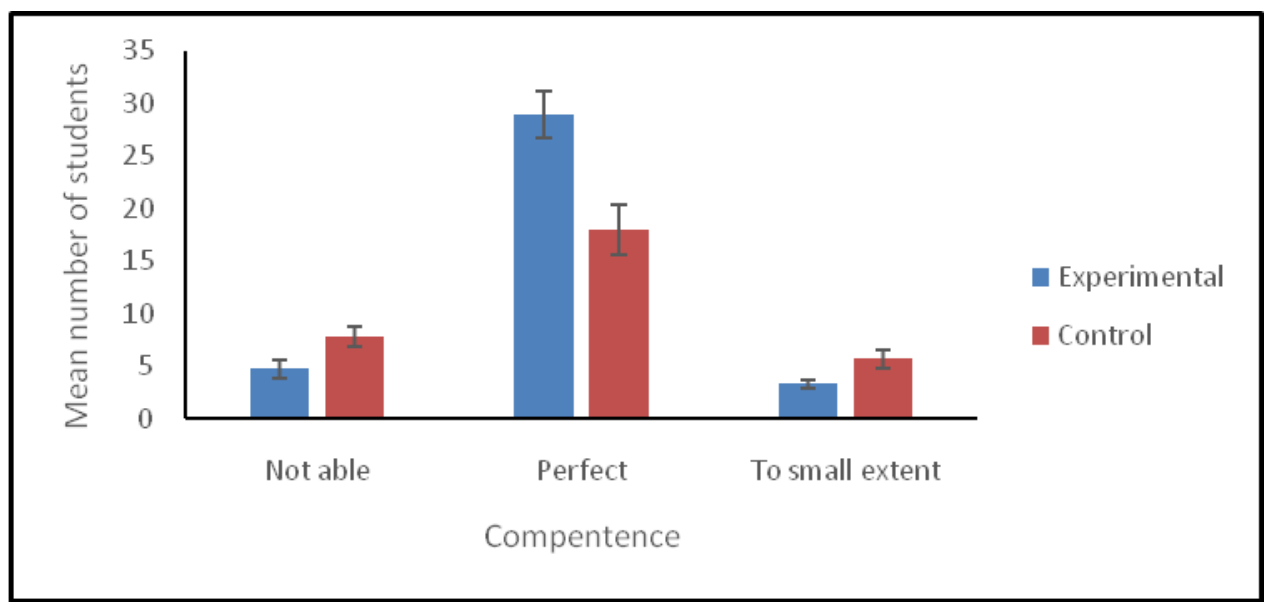

Figure 4.4: comparison of experimental and control groups on the three process skills.

In comparing the two groups, the number of those who were proficient was high in experimental group. This implies that the treatment given had a positive impact.

\section{DISCUSSION}

The study found out that the experimental schools acquired the skills better than control schools. The $\mathrm{p}$-values for the different competencies are as follows Unable $\mathrm{p}=0.0238$, to small extent $\mathrm{p}=0.0160$, Proficient $\mathrm{p}=0.0026$ while the $\mathrm{t}$-values are $2.4,2.5764$ and 3.3294 respectively.

The findings of this study concur with the findings of Bang and Baker (7) that found out that, students in mixed secondary schools had good acquisition of process skills. In addition the findings affirm Ndoro (2017) use of direct assessment of skills is the best for the novice scientists.

In conclusion, figure 4.4 clearly depicts that there is no significance difference in the process skills acquisition for the experimental and control groups. Therefore in regards to this study, the second hypothesis, $\mathrm{H}_{\mathrm{O}}$ : There is no significant difference in acquisition of science process skills for students taught chemistry through experimental approach and those not taught through experimental approach is upheld.

\section{REFERENCES}

Sharples, M., de Roock, R., Ferguson, R., Gaved, M., Herodotou, C., Koh, E., ... \& Weller, M. (2016). Innovating pedagogy 2016: Open University innovation report 5.

Schutt, R. K. (2018). Investigating the social world: The process and practice of research. Sage Publications.

Rodney, W. (2018). How europe underdeveloped africa. Verso Trade. 
Ganimian, A. J., \& Murnane, R. J. (2016). Improving education in developing countries: Lessons from rigorous impact evaluations. Review of Educational Research, 86(3), 719-755.

Anderson, E. (2018). A Focus on Scientific Inquiry in CTE through a Green Space.

Blagdanic, S., Kadijevic, G. M., \& Kovacevic, Z. (2019). Gender stereotypes in preschoolers' image of scientists. European Early Childhood Education Research Journal, 1-13.

Kenya National Examination Council Report, 2016. Kenya Certificate of Secondary Education Chemistry (KCSE) Newsletter, Nairobi.

Kenya National Examination Council Report, 2017. Kenya Certificate of Secondary Education Chemistry (KCSE) Newsletter, Nairobi.

Bang, E., \& Baker, D. (2013). Gender differences in Korean high school students' science achievements and attitudes towards science in three different school settings. Mevlana International Journal of Education, 3(2),27-42. http://dx.doi.org/10.13054/mije.13.11.2018

Ndoro, M. C. (2017). Learner performance in integrated science process skills and attitudes in hands-on practical work versus virtual practical work (Doctoral dissertation, University of Cape Town). 